\title{
Poetry, paradox and the Psalms
}

\section{Jock Stein}

There are several kinds of paradox. There are those which fool you with sleight of hand, like the grandfather paradox, where someone travels through time to the past, kills their grandfather, and so could not be alive to undertake the journey. Philosophers enjoy discussing this kind of paradox, an even more famous one being the liar paradox. In the 1967 Star Trek episode "I, Mudd", Captain Kirk warns the android leader that everything Harry says is false. Harry then says, 'I am lying. ${ }^{1}$

There are other kinds of paradox which scientists and philosophers appreciate, and generally have solved, or lived with over the years. Some arise out of the complexity of modern physics, which may or may not be resolved as science advances. Take the definition of paradox as a set of mutually inconsistent propositions, each of which seems true: ${ }^{2}$ then a modern classic is the assertion, first, that quantum mechanics is the most accurate way to describe the nature of matter, and second, the conclusion from the same quantum mechanics that two things can influence one another even without any contact between them, known as 'entanglement'. ${ }^{3}$ A simpler way of stating essentially the same paradox is that light is both waves and particles, sometimes used as an illustration for the doctrines of Incarnation or Trinity.

The poet uses paradox in a trivial way when, like any writer, she lies in using 'I' to inhabit a character who is not herself (indeed just as a male writer is in this very sentence describing himself as 'she'). However the poet can use paradox in a deeper sense without having to worry about resolutions, and thus evoke new ways of thinking and feeling:

O world invisible, we view thee,

$\mathrm{O}$ world intangible, we touch thee, 
O world unknowable, we know thee,

Inapprehensible, we clutch thee! ${ }^{4}$

It's as if the crucified God, for a moment, finds himself an atheist. ${ }^{5}$

The cross is a fruitful inspiration for the poetry of paradox, as in Vassar Miller's poem:

You crucify me safe from crucifixion ${ }^{6}$

In this next example, paradox blends into metaphor, asserting a contradiction in how trees behave:

Was he balked by silence? He kneeled long

And saw love in a dark crown

Of thorns blazing, and a winter tree

Golden with fruit of a man's body.?

Because people are less predictable than plants, paradox becomes less surprising with humans. People say they are concerned about the use of their personal data, yet perfectly happy to give it up - a paradox that keeps Facebook in business. A Church of Scotland survey found church members concerned about their lack of knowledge of the Christian faith, but unwilling to attend courses which might remedy that. Paul put this dramatically in Romans 7.

David Daiches in The Paradox of Scottish Culture ${ }^{8}$ describes the way farmers and merchants could cite Calvinism to oppose progress in agriculture and finance, when Calvin actually commended such freedom of action. ${ }^{9}$

A classic poem about the paradox of being human is "The Riddle of the World", by Alexander Pope, which describes a human as:

Great lord of all things, yet a prey to all, Sole judge of truth, in endless error hurl'd;

The glory, jest and riddle of the world. 
And a contemporary poet acknowledges the virtue of paradox:

where opposites can meet and then depart

in curves of paradox which shape the light: ${ }^{10}$

\section{Paradox in the Psalms}

There are explicit literary devices in the Psalms, such as the use of chiasm, parallelism and acrostic, but paradox is often present in what is being said.

The writer of Psalm 26 claims present innocence and past integrity. The psalm is connected with David by its later superscription, yet only a young David could express words like these with any honesty. But the psalm also expresses a love for God's house, which means that even if it were written by David it must be later in his life. Historians can resolve this paradox by saying it was written by a later hand - but poetry enjoys such paradoxes, which cast into relief the contradictions of human life, and help us feel both delight in innocence, and disgust at hypocrisy, all at the one time. Here is the first verse of my own poem on Psalm 26 called "Aye Right":

Gin Davie gat tae screivin wirds lik thase, lang wirds lik integritie, an nae jist yince, e maun hae thocht hissel agin a laddie.

It might be claimed that God is more predictable than humans - but in the Bible God likes to change his mind. ${ }^{11}$ Now, if theology is simply the use of imaginative language to describe what is beyond all words ${ }^{12}$ and if the Bible likewise is simply imaginative and poetic literature, then there is little more to be said than to illustrate how the Book of Psalms revels in such paradox:

Because you have made the LORD your refuge

the Most High your dwelling place, no evil shall befall you; no scourge come near your tent. ${ }^{13}$ 
O God, why do you cast us off forever?

Why does your anger smoke against the sheep of your pasture? ${ }^{14}$

O give thanks to the LoRD, for he is good, for his steadfast love endures forever. ${ }^{15}$

But the Psalms are not just poetry, but the poetry of a people who had a particular view of God, and a trust in that God; they are poetry preserved and treasured by a people who have had to live and think through that faith in spite of hardship and persecution, up to and beyond the tragedy of the Shoah. ${ }^{16}$

The Psalms can be used to explore the paradox of a faith which seems not to work at all, as Jacqueline Osherow does in considering Auschwitz through the lens of Psalm 37:25. She shows how the rabbinic explanation that the Psalms are not to be taken literally does not quite wash. ${ }^{17}$

So, if one rejects the weasel word 'simply' as in 'simply the use of imaginative language' above (sometimes called 'nothing buttery'), then the paradoxes of the Bible may throw more light on God, and on the human condition, than a 'simple' poetic understanding reveals, and - like good religion at any time - provoke a deeper response of feeling as well as thought, because we are not just encountering great literature, but the struggle of a people with faith and destiny. The very name Israel means 'God strives' or 'The one who struggles with God'. ${ }^{18}$

Of course, often enough a single psalm will say things about God that appear to be contradictory, for example in Psalm 22, which begins with a cry about God's absence, but closes with an orthodox affirmation of his help. The point stands even if you think the final verses are a later addition, as we are then dealing with what editors thought should be one psalm.

In the Book of Psalms we have a literature which is sui generis. There are superficial parallels with other writings, but if there ever was 'an axial age' in the millennium before Christ, when the sages of various religions took a great step forward to encourage people to look within themselves for wisdom instead of to the experts, the Book of Psalms is not part of that. ${ }^{19}$ 
Where there is of course a parallel with other writings is in the use of paradox to understand and feel the dilemmas of the human condition. Virgil had his own ways of doing this. 'The Aeneid', says Jackson Knight, 'was created with both mighty inspiration and immense labour'20 and this 'both-and' is demonstrated in the careful structuring of the chiastic Psalm 29, or the acrostic Psalm 119, both of which at the same time give total credit to their God Yahweh. Virgil was presenting 'a true poetic picture of the world' ${ }^{21}$ in the way he inter-related the doings of gods and humans, but while this was very different from how the writers of the Psalms saw the world, Virgil also had to deal carefully with paradox, since 'Jupiter of course had to see both sides of the question'. ${ }^{22}$

\section{The Psalms and Scottish writers}

The Psalms do not yet reach the great paradox of the New Testament,

So man cried, but with God's voice.

And God bled, but with man's blood ${ }^{23}$

but they are a literature which influenced Scottish writers at least up to the middle of the twentieth century. Of James Hogg, the Ettrick Shepherd, it is said that the Psalms were 'the central literary text which Hogg himself paid tribute to' ${ }^{24}$ although strangely, Hogg is typical of many writers when he always refers to people singing the psalms rather than to the psalms themselves. ${ }^{25}$

Indeed, all the classic texts in the Scottish Religious Poetry anthology, ${ }^{26}$ if they mention the Psalms, cite them simply as something sung, and when they mention the Bible, always refer to doctrine and story rather than explicitly citing the Psalms. Robert Allan writes naturally:

O wha will gang to yon hill-side,

To sing the psalm at een? ${ }^{27}$

It is true that Dallan Forgaill's "Elegy of Columba" says, '[God] fixed the Psalms' ${ }^{28}$ There is the prose version of Psalm 100 in that Anthology, since it was written by a Scottish poet, along with the prose version 
of Psalms 23 and 128. There is the reference to psalm tunes in "The Cottar's Saturday Night". Violet Jacobs writes of a voice drowning out the Psalms and Paraphrases. But citations from the Psalms in the poems are absent from this anthology, while angels, apocalypse, ascension, Christ and his work, creation, grace, Job, judgment, law and Moses, love, Mary, saints and popes, Sabbath, Satan, the Song of Songs, the Trinity, are frequent.

Robert Henryson's "The Preiching of the Swallow", a religious poem, is about the swallow as a bird of nature, without reference to Psalm 84. The brown stag of Donald Macdonald is on the moor, not in Psalm 42. Nan Shepherd's "O, Licht amo' the Hills" has nothing to do with Psalm 121. Donald Macaulay 'listened to the psalm' - while 'the tune was mysterious', that is all we get. Catriona Montgomery's 'blackness of the pit' ${ }^{29}$ might have come from a dozen psalms if she had not included 'black', making it come from none.

In their Introduction to the anthology, the editors suggest that the Scottish poetic tradition is better represented by those like Norman MacCaig and Sorley Maclean who manage to link the sublime and the mundane without positing a contrast between this world and another world, since they stay 'locked in the human cage'. ${ }^{30}$ It is more common today to find 'psalm' used in a vaguely spiritual sense, rather than a 'Bible' sense, as John Burnside writes of 'the people in a psalm [...] arriving here by chance, just passing through.' ${ }^{31}$

\section{Paradox and Scottish poetry in the twentieth century}

All literature is enriched by its context, including Scottish literature, and great literature is likely to embrace paradox to describe the human condition:

The literature of Scotland [...] is a literature packed with paradox. The Scottish contribution to European Romanticism, for example, was profound, formative and, almost simultaneously, subversive of it. ${ }^{32}$

Christopher Grieve in choosing the name and character of Hugh MacDiarmid embraced paradox in himself as well as in his writing. 
Boutelle borrows MacDiarmid's own Hegelian view of thesis and antithesis to comment: 'MacDiarmid is a poet of paradox [...] His poetic role is to bring unity, to make possible a synthesis [...] the form that this paradox takes is an attempt to return to pre-Fall Eden in order to reach future paradise.' He reverses T. S. Eliot's 'In my end is my beginning' to 'In my beginning is my end'. ${ }^{33}$

He used the nature of a thistle to look at so many prickly psychological, philosophical, political problems 'suggested in terms of pairs of contraries: lust (the thorn in the flesh) and love, body and soul, passion and intellect, [...] the real and the ideal, God and man, chaos and cosmos, oblivion and eternity.' High national aspirations are yoked to 'a mere weed. ${ }^{34}$

The contradiction which MacDiarmid is wrestling with is well expressed by:

The thistle rises and forever will,

Getherin' the generations under't.

This is the monument o' a' they were,

And a' they hoped and wondered. ${ }^{35}$

Here the thistle is a gravestone as well as a symbol of hope, which is part of the paradox of the 'Caledonian Antisyzygy' (the term was invented by Gregory Smith in 1919). ${ }^{36}$

Less controversial, the poet Edwin Muir was familiar with paradox in a biblical context, whether in a light use such as 'corn and tares compactly grown' or a more solid use like 'The Word made flesh is here made word again'. ${ }^{37}$

While MacDiarmid as an atheist was still happy to use biblical imagery, another less famous Scottish poet used a biblical paradox in writing about his life as a Fife miner:

Crawlin' aboot like a snail in the mud,

Covered wi' clammy blae,

ME, made after the image of God -

Jings! but it's laughable, tae. ${ }^{38}$ 
Corrie continued a long tradition of using the Bible to draw attention to hypocrisy (one form of paradox in action), as Burns did in "Holy Willie's Prayer".

\section{Poetry, paradox and the Psalms today}

Fewer poets in Scotland mention the Psalms today, one reason clearly being the decline of knowledge of the Bible, and classical languages in general, ${ }^{39}$ a different reason being the desire, as the poet Ezra Pound used to put it, to 'make things new'. References to them are likely to be set in a historical context, as Karla Van Vliet does when writing about a little-known saint in her poem "On Brenhilda of Sula Sgier"; this is a section of the poem called "The Wind": 40

Why she had come to this far skerry that climbs from the Atlantic's gray-waters we heard in whisperings on Rona.

Her brother, that sainted head, had an eye for her beyond his oath. And to save from violation the virtue of her holy vocation, she expelled herself; the rumours had it.

We knew her fierceness, recognised the storm in her voice.

That ferocity we, too, carried in our being. A kind of hell's fury, some sailors said.

But people often get it wrong, her intensity stood for love; we heard that in the quality of her song, her crying faithfulness of heart.

Remember we entered her in every breath. Her body shaped us into bird and flung us baring psalms into the sacred blue of sky.

The day she did not take us in, we sang lament.

Loneliness has been known to shatter a human heart, so completely, that even God cannot mend.

'Baring psalms' comes thus in a song of lament at the paradox of earthly lust so close to sainthood, and the possibility there may be things an almighty God cannot fix. A good poem leaves you wondering, and the use of 'baring' in that context does just that. Here is an example 
of paradox in a poem "which is also exploring the paradox of women (and men) finding they need to withdraw from the world to fulfil their vocation'. ${ }^{41}$

The word 'psalm' is often referenced in modern poetry as a word for something special, rather than a biblical psalm. John Deane, who writes prolifically about religion, uses 'psalm' for the paradox of speech without words:

I spoke a psalm, language

but no words, within me. ${ }^{42}$

His Drysalter, ${ }^{43}$ with its 150 poems of 15 lines - perhaps hinting that there is more to the Psalms than there is to sonnets - is clearly referencing the Book of Psalms. There are six 'Portraits of the Psalmist' and other allusions such as "The Darkness is No Darkness" (Psalm 139). It is full of the use of paradox, for example:

Because the sun has a dark heart, the heart must have a dark sun shut inside, unable to raise or blaze or set. ${ }^{44}$

Toby Martinez de las Rivas calls his latest book Black Sun, and has a quote from Psalm 90:4 at the start, ' $\ldots$ as a watch in the night'.

Rather than 'the Psalmist', Andrew Philip, a Scot whose poetry has something in common with Symmons Roberts, uses the figure of 'MacAdam' in a similar way, but while paradox often features in his poetry, ${ }^{45} \mathrm{I}$ can only find one poem, "Summa", which might be referencing a psalm (Psalm 150 in this case) ${ }^{46}$

Maria Apicella called her epic poem cycle Psalmody, and it is largely about a journey with God and with her boyfriend David, 'an atheist after God's own heart', ${ }^{47}$ a nice touch of paradox. How does she spend her days? 'Chewing the psalms of David.' 48

Malcolm Guite has a book called Parable and Paradox. Although there is the odd reference to a psalm (the 'tent' of Psalm 19 in one), he finds the gospels a more fruitful source of paradox for his poetry. In his Sounding the Seasons, a poem called "Hide and Seek" refers to 
the paradox of Psalm 139:12, 'Even in darkness I can see you shine'. In "St. Augustine and the Reapers", he refers to Psalm 126:5, 'Those who sow in tears will reap in joy'. ${ }^{49}$

Jacqueline Osherow has a section of her book Dead Men's Praise called "Scattered Psalms". One of these cites several verses from the same psalm (Psalm 18:11-12 and 29) which present the paradox of God as concealed in the dark, yet giving us light. ${ }^{50}$

Edward Clarke has a booklet just out called Eighteen Psalms. From Psalm 14 (53) he describes the strangeness, perhaps, rather than the paradox of human folly:

I read an Idiot's Guide to get this straight, to prove we are today all apostate, or complex, or fluid.

The substance of these words presents to me an almost duplicate identity

to hammer home

this point that we've betrayed the truth, the Word that's nailed to metaphors, its trace deferred in time that's flown. ${ }^{51}$

Neither Deane, Roberts, Apicella, Guite, Osherow nor Clarke are Scottish. Among Scottish poets, Diana Hendry, who wrote twelve versions of psalms in Scots, ${ }^{52}$ has a recent everyday reference to Psalm 23:

I remember we had wandered off, were lying among tall grasses soft as those in the twenty-third psalm. ${ }^{53}$

Fearghas MacFhionnlaigh cites a verse from Psalm 24 as a 'chorus' in his unpublished poem "Eagle, Robin, Pine". ${ }^{54}$ Lezley Stewart has written prayers for public worship which include loose modern paraphrases of the Psalms ${ }^{55}$ (somewhat similar to Carla GroschMiller's Psalms Redux). Sam Tongue references the $121^{\text {st }}$ Psalm in the poem "Capel-y-Ffin" in his book Hauling-Out, ${ }^{56}$ though the context is historical (the stained glass in a remote Welsh chapel). 
Lyn Moir in New Writing Scotland 21 has a poem called "Sea Leopard". ${ }^{57}$ It appears to reference verses from three psalms (Psalm 89:9; Psalm 98:7; Psalm 107:25), but the power of the sea is in the paws of a leopard, not the hands of God, and it is nature that is more likely to be given divine status in contemporary poetry. Fran Lock writes in her poem "Epistle from Within the Sharknado": ${ }^{58}$

You might call it God, but it's not God. The sky is singing with Nature's maniac gusto. It's the only game in town.

More intentionally, the Shetlandic poet Christine de Luca not only refers to old psalms that 'transept the silence' at Stobo Kirk, but as well as four Shetlandic poems which reference psalms - has two specific references in her English poetry. She refers to Psalm 81:7 in "Streams in the Desert" but engages paradox full on with her poem on the Lockerbie Pan Am disaster in 1988, which takes Psalm 16:6 and begins 'Life falls in pleasant places'. ${ }^{59}$

Whereas the paradox, of course, lies in the pun on 'falls', behind the linguistic use is the enduring paradox of God making a good world in which bad things happen, and this is a baseline of both literature and theology, whether it is described as 'Nature's maniac gusto' or 'one foot in Eden'.

There are other contemporary poets like Maoilios Caimbeul, writing mainly in Gaelic, and Harry Smart who do treat the psalms seriously. In a poem ${ }^{60}$ called "The Wren", Smart muses on the idiocy of someone setting Psalm 46 to the tune "Dambusters", with the terrible collateral effect of the bombs downstream of the dam:

And my mind had turned to the Möhne Dam:

how the voice of engines went over the waters, the voice of the Lancasters, the bombs of glory thundered, the bombs of God.

The Psalm itself commands:

Be still and know that I am God ${ }^{61}$ 
put in the mouth of a God who 'utters his voice, and the earth melts' ${ }^{92}$ but also 'breaks the bow and shatters the spear'. ${ }^{63}$ Paradox is safer in God's hands than ours, suggests Campbell.

\section{Conclusion}

While the psalms are not referenced by writers generally as often as other parts of the Bible, they have inspired some contemporary poets as they reflect on life and its strange features, sometimes amounting to paradox. Even the fact that psalms like 5 and 69 combine lament and praise is in its way a paradox, though in fits and starts the five books of Psalms do present a transition from lament to praise.

When theology was more cut and dried, paradox was sometimes thought to be the refuge of a theological scoundrel, but the complexities of modern science, and interpretation 'in front of' the text as well as 'behind the text' have in different ways reinstated the value of paradox, which has always had its use as a term to recognise the mysteries at the heart of the universe and human life, let alone Christian theology. ${ }^{64}$

After all, in the root meaning of the word, paradox can mean 'close to glory' or even 'beyond the marvellous' as well as simply 'not what it seems'.

\section{Notes}

1 Roy A. Sorensen, A Brief History of the Paradox: Philosophy and the Labyrinths of the Mind (New York: OUP, 2003), 197.

2 Margaret Cuonzo, Paradox (Cambridge, Mass.: MIT Press, 2014), 204.

3 John Polkinghorne, Quantum Theory: A Very Short Introduction (Oxford: OUP, 2002), esp. 77f.

4 From "In No Strange Land" by Francis Thompson (1859-1907).

5 From Ecumenical Patriarch Bartholomew's meditation on the cross, in Olivier Clément, Conversations with Ecumenical Patriarch Bartholomew I (Crestwood, NY: St Vladimir's Seminary 
Press, 1997), 240f., 258f. Cited in Bartholomew, Encountering the Mystery (New York: Doubleday, 2008), Foreword xxi.

6 From Vassar Miller, "Paradox", in The Lion Christian Poetry Collection, compiled by Mary Batchelor (Oxford: Lion Publishing, 1995).

7 From R. S. Thomas, "In a Country Church", in Song at the Year's Turning: Poems 1942-1954 (London: Hart-Davis, 1955), 67.

8 David Daiches, The Paradox of Scottish Culture: The Eighteenthcentury Experience (London: Oxford University Press, 1964), 40.

9 Breaking away from the medieval consensus against charging interest, both Calvin and Luther left it to the individual conscience - see e.g. Eric Kerridge, Usury, Interest and the Reformation (Aldershot; Burlington Vt.: Ashgate, 2002), chapters 1-2 and esp. pp. 51-52. Calvin has even been called the father of modern capitalism, as he distinguished interest on loans for consumption and interest on loans for production.

10 Micheal O'Siadhail, The Five Quintets (Waco, Tex.: Baylor University Press, 2018), 355.

11 Exodus 32:14, Jonah 3:10.

12 As in, for example, J. L. Houlden in The Myth of God Incarnate, ed. John Hick (London: SCM, 1977). There is a good discussion of this in the Preface of T. F. Torrance, Theological Science (Oxford: OUP, 1969).

13 Psalm 91:9-10.

14 Psalm 74:1.

15 Psalm 136:1.

16 See for example, chapter 1 of Jakób Jocz, The Jewish People and Jesus Christ After Auschwitz (Grand Rapids, Mich.: Baker, 1981).

17 Jacqueline Osherow, Dead Men's Praise (New York: Grove Press, 1999), 63.

18 A name given to Jacob after wrestling with the angel, wonderfully portrayed by Michael Symmons Roberts in his poem "Choreography".

19 An idea popularised by Karen Armstrong, but now discredited. See Iain Provan, Convenient Myths: The Axial Age, Dark Green 
Religion, and the World that Never Was (Waco, Tex.: Baylor University Press, 2013), 35f.

20 Virgil, The Aeneid, translated with an introduction by W. F. Jackson Knight (London: Penguin, 1956), 16.

21 Ibid., 14.

22 Ibid., 13.

23 Ted Hughes, "Crow Blacker than Ever", in Crow: From the Life and Songs of the Crow (London: Faber, 1972), 69. Cited in Mark Oakley, The Collage of God (London: Canterbury Press, 2012), 27.

24 Ian Campbell, "James Hogg and the Bible", in The Bible and Scottish Literature, ed. David F. Wright (Edinburgh: Saint Andrew Press, 1988), 100.

25 In The Private Memoirs and Confessions of a Justified Sinner (London: Philpot, 1926), Hogg refers to singing part of the $10^{\text {th }}$ Psalm (192) and part of the $119^{\text {th }}$ Psalm (227). In The Shepherd's Calendar, ed. Douglas S. Mack (Edinburgh: Edinburgh University Press, 1995) where you might expect some reference to the $23^{\text {rd }}$ Psalm, he only refers to the singing of psalms, and the reading of Ezra. In his poems, we get no further than 'The psalm was read' in "The First Sermon" (James Hogg, Selected Poems and Songs, ed. David Groves [Edinburgh: Scottish Academic Press 1986], 170), and a reference to 'Salem's harp' in "The Pilgrims of the Sun".

26 Meg Bateman, Robert Crawford and James McGonigal, eds., Scottish Religious Poetry: From the Sixth Century to the Present: An Anthology (Edinburgh: Saint Andrew Press, 2000).

27 Robert Allan, "The Twa Martyrs' Widows" in ibid., 164.

28 Ibid, 15.

29 Catriona NicGumaraid/Montgomery, “Dàn/Song”, in ibid., 291.

30 Ibid., xxvii, citing George Campbell Hay.

31 John Burnside, "Canticle", in ibid., 297.

32 Alan Riach, "Reading Hugh MacDiarmid", in Hugh MacDiarmid: Selected Poetry, eds. Alan Riach and Michael Grieve (Manchester: Carcanet Press, 1992), xv.

33 Ann Edwards Boutelle, Thistle and Rose: A Study of Hugh MacDiarmid's Poetry (Lewisburg, Pa.: Bucknell University Press, 1980), $10 \mathrm{f}$. 
Kenneth Buthlay "Introduction", in Hugh MacDairmid, A Drunk Man Looks at the Thistle: An Annotated Edition (Edinburgh: Scottish Academic Press, 1987), xxvi.

35 "A Drunk Man Looks at the Thistle", lines 2232-35 in Hugh MacDiarmid: New Selected Poems, ed. Alan Riach and Michael Grieve (London: Carcanet, 1992).

36 Buthlay, "Introduction", in A Drunk Man, xxiii.

37 In the poems "One Foot in Eden" and "The Incarnate One", in Edwin Muir: Collected Poems (London: Faber \& Faber, 1960), 227, 228.

38 Joe Corrie, “The Image o' God". Cited in William Storrar, Scottish Identity: A Christian Vision (Edinburgh: Handsel, 1990), 193.

39 When Kipling wrote his poem about the Scottish railway engineer seeing predestination in 'the stride o' yon connecting-rod', he referred to the Latin word Institutio for Calvin's Institutes of the Christian Religion - how many people today would know that book in English, let alone in Latin?

40 The poem is published in Acumen 91 of May 2018, cited by permission of the author.

41 E-mail from the author to the writer, January 2019.

42 From "Mount Hermon", in John F. Deane, Semibreve (Manchester: Carcanet, 2015), 120.

43 Michael Symmons Roberts, Drysalter (London: Cape, 2013).

44 "Ascension", in ibid., 11.

45 For example, 'God the mother lifts to her face/chaos/for that first/ fond kiss' in "Breathing is the Place to Start", from The North End of the Possible (Cromer: Salt Publishing, 2013), 45.

46 In The Ambulance Box (Cambridge: Salt Publishing, 2009).

47 Maria Apicella, Psalmody (London: Eyewear Publishing, 2016), 112.

48 Ibid., 27.

49 A sonnet written for Jeremy Begbie's Redeeming Transcendence in the Arts: Bearing Witness to the Triune God (Grand Rapids, Mich.: Eerdmans, 2018).

50 Osherow, Dead Men's Praise, 57.

51 Edward Clarke, Eighteen Psalms (Plymouth: Periplum, 2018). 
52 Diana Hendry, Twelve Lilts: Psalms and Responses (Glasgow: Mariscat Press, 2003).

53 From "The Beaten Track", in Diana Hendry The Watching Stair (Tonbridge: Worple Press, 2018).

54 Held by the Handsel Press in Haddington.

55 Lezley J. Stewart, Let Everyone Find Their Voice: Prayers for Public Worship. Self-published, but used by the Church of Scotland Ministries Council.

56 Samuel Tongue, Hauling-Out (London: Eyewear Publishing, 2016).

57 In Milking the Haggis: New Writing Scotland 21, eds. Valerie Thornton and Hamish Whyte (Glasgow: Association for Scottish Literary Studies, 2004).

58 National Poetry Competition 2016 (The Poetry Society).

59 "Life Falls in Pleasant Places", in Voes and Sounds: Poems in English and Shetland Dialect (Lerwick: The Shetland Library, 1994).

60 Unpublished, I think.

61 Psalm 46:10.

62 Psalm 46:6.

63 Psalm 46:9.

64 In Redeeming Transcendence in the Arts (op. cit.) Jeremy Begbie cites a number of modern theologians in support of this (see especially pages 120f.), let alone the apophatic tradition of the Eastern Church. 